\title{
Methanol and isoprene emissions from the fast growing tropical pioneer species Vismia guianensis (Aubl.) Pers. (Hypericaceae) in the central Amazon forest
}

\author{
Kolby J. Jardine ${ }^{1}$, Angela B. Jardine ${ }^{2}$, Vinicius F. Souza ${ }^{2}$, Vilany Carneiro ${ }^{2}$, Joao V. Ceron ${ }^{2}$, Bruno O. Gimenez ${ }^{2}$, \\ Cilene P. Soares ${ }^{2}$, Flavia M. Durgante ${ }^{2}$, Niro Higuchi ${ }^{2}$, Antonio O. Manzi ${ }^{2}$, José F. C. Gonçalves ${ }^{2}$, Sabrina Garcia ${ }^{2}$, \\ Scot T. Martin ${ }^{3}$, Raquel F. Zorzanelli ${ }^{2}$, Luani R. Piva ${ }^{2}$, and Jeff Q. Chambers ${ }^{1,4}$ \\ ${ }^{1}$ Climate and Ecosystem Sciences Division, Earth Science Division, Lawrence Berkeley National Laboratory, \\ One Cyclotron Rd, Berkeley, CA 94720, USA \\ ${ }^{2}$ National Institute for Amazon Research (INPA), Ave. Andre Araujo 2936, Campus II, Building LBA, \\ Manaus, AM 69.080-97, Brazil \\ ${ }^{3}$ School of Engineering and Applied Sciences and Department of Earth and Planetary Sciences, Harvard University, \\ Cambridge, MA, USA \\ ${ }^{4}$ Department of Geography, University of California Berkeley, 507 McCone Hall \#4740, Berkeley, CA 94720, USA
}

Correspondence to: Kolby J. Jardine (kjjardine@lbl.gov)

Received: 25 January 2016 - Published in Atmos. Chem. Phys. Discuss.: 11 February 2016

Revised: 22 April 2016 - Accepted: 9 May 2016 - Published: 26 May 2016

\begin{abstract}
Isoprene (Is) emissions by plants represent a loss of carbon and energy resources leading to the initial hypothesis that fast growing pioneer species in secondary tropical forests allocate carbon primarily to growth at the expense of isoprenoid defenses. In this study, we quantified leaf isoprene and methanol emissions from the abundant pantropical pioneer tree species Vismia guianensis and ambient isoprene concentrations above a diverse secondary forest in the central Amazon. As photosynthetically active radiation (PAR) was varied (0 to $3000 \mu \mathrm{mol} \mathrm{m}{ }^{-2} \mathrm{~s}^{-1}$ ) under standard leaf temperature $\left(30^{\circ} \mathrm{C}\right)$, isoprene emissions from $V$. guianensis increased without saturation up to $80 \mathrm{nmol} \mathrm{m}^{-2} \mathrm{~s}^{-1}$. A nonlinear increase in isoprene emissions with respect to net photosynthesis (Pn) resulted in the fraction of Pn dedicated to isoprene emissions increasing with light intensity (up to $2 \%$ of $\mathrm{Pn})$. Emission responses to temperature under standard light conditions (PAR of $1000 \mu \mathrm{mol} \mathrm{m}^{-2} \mathrm{~s}^{-1}$ ) resulted in the classic uncoupling of isoprene emissions $\left(T_{\mathrm{opt}, \text { iso }}>40^{\circ} \mathrm{C}\right)$ from net photosynthesis $\left(T_{\mathrm{opt}, \mathrm{Pn}}=30.0-32.5^{\circ} \mathrm{C}\right)$ with up to $7 \%$ of Pn emitted as isoprene at $40^{\circ} \mathrm{C}$. Under standard environmental conditions of PAR and leaf temperature, young V. guianensis leaves showed high methanol emissions, low Pn, and low isoprene emissions. In contrast, mature leaves showed high Pn, high isoprene emissions, and low methanol emis-
\end{abstract}

sions, highlighting the differential control of leaf phenology over methanol and isoprene emissions. High daytime ambient isoprene concentrations (11 ppbv) were observed above a secondary Amazon rainforest, suggesting that isoprene emissions are common among neotropical pioneer species. The results are not consistent with the initial hypothesis and support a functional role of methanol during leaf expansion and the establishment of photosynthetic machinery and a protective role of isoprene for photosynthesis during high temperature extremes regularly experienced in secondary rainforest ecosystems.

\section{Introduction}

Due to its vast territorial expansion, high species diversity, and long growing season, the Amazon forest in South America is responsible for an estimated $15 \%$ of global terrestrial photosynthesis (Malhi et al., 2008). However, increased deforestation, degradation, and natural disturbances have changed this scenario, exerting strong control on the evolution of atmospheric $\mathrm{CO}_{2}$ (Pan et al., 2011; Malhi et al., 2008). A recent analysis of biomass dynamics revealed 
a long-term trend of increased mortality-driven shortening of carbon residence times in the Amazon forest (Brienen et al., 2015). This effect has been attributed to increased climate variability, as recurrent drought episodes occurred in the region (Phillips et al., 2009; Lewis et al., 2011). Amazon carbon sink suppression during the intense drought period in 2005 was associated with a decrease in biomass gain and increased vegetation mortality (Phillips et al., 2009). Changes in forest turnover rate can directly affect forest composition and structure; the creation of forest gaps leads to the release of suppressed trees and increased pioneer species recruitment rates (Bugmann, 2001). Tropical forest regrowth has been identified as a strong terrestrial carbon sink that can partly counterbalance carbon losses by deforestation and forest degradation (Pan et al., 2011). If tropical forests are becoming more dynamic, gap-phase processes can therefore play a more central role in determining carbon residence times, which have been described as the largest uncertainty in terrestrial vegetation responses to climate and elevated $\mathrm{CO}_{2}$ (Friend et al., 2014).

The classic neotropical pioneer genera Vismia and $\mathrm{Ce}$ cropia dominate large rainforest disturbance gaps in the Amazon basin (Chambers et al., 2009) where they help accelerate the regeneration of secondary forests by influencing forest successional pathways (Uhl et al., 1988; Vieira et al., 2003; Zalamea et al., 2008). Their success in secondary forests is related to their ability to maintain high rates of net photosynthesis $(\mathrm{Pn})$ and growth under conditions of full sunlight, high leaf temperatures, and low nutrient availability, often characteristic of tropical landscapes impacted by natural (Chambers et al., 2009) and human (Mesquita et al., 2001) disturbances. Under optimal environmental conditions for photosynthesis, emissions of volatile isoprenoids by leaves of many plant species can account for a few percent of Pn (Kesselmeier et al., 2002). However, under stress conditions that diminish Pn but increase isoprene (Is) emissions such as high leaf temperatures, emissions of Is can account for over $50 \%$ of Pn (Jardine et al., 2014). While investments into Is production remain poorly understood among tropical plants (Harley et al., 2004), the pattern of the photosynthetic carbon allocation has been discussed through carbon-nutrient balance and growth-differentiation balance hypotheses (Stamp, 2004; Glynn et al., 2007; Massad et al., 2012). These hypotheses predict the existence of trade-off between investment in growth versus plant defense.

Thus, a hypothesis can be considered that fast growing pioneer tree species in secondary forests do not produce volatile isoprenoids as secondary metabolites and instead dedicate these carbon and energy resources to primary metabolites for enhanced biomass production and growth or increased catabolism for energy generation during growth and maintenance respiration. However, this hypothesis is not well supported in the literature as early successional pioneer species have been observed with high volatile isoprenoid emission rates (Klinger et al., 1998; Jardine et al., 2015).
An alternative hypothesis that is well supported in the literature is that investment of carbon and energy resources into Is and monoterpene production and emissions by secondary forest species protects photosynthesis during abiotic stress including high temperature stress, possibly through antioxidant and energy/reducing equivalent consumption mechanisms (Vickers et al., 2009a, b; Jardine et al., 2012b; Penuelas and Llusia, 2002; Grote et al., 2014; Loreto and Velikova, 2001). Additional studies revealed possible connections between volatile isoprenoid emissions and increased photorespiration during high leaf temperatures (Jardine et al., 2014) and drought stress (Dani et al., 2014). Consistent with these potentially important functional roles for pioneer species, a leaf and branch survey at four neo-tropical sites (Harley et al., 2004) suggested that Vismia guianensis is an Is producer with a single leaf emission value of $48 \mu \mathrm{g} \mathrm{Cg}^{-1} \mathrm{~h}^{-1}$ reported (or $11 \mathrm{nmol} \mathrm{m}^{-2} \mathrm{~s}^{-1}$ assuming a specific leaf area of $20 \mathrm{~m}^{2} \mathrm{~kg}^{-1}$ ) (Dias-Filho, 1995). A survey of Is emissions from tropical central Africa suggested that Is emissions are higher in early successional forest communities relative to primary forests (Klinger et al., 1998). In addition to Is, more recent field studies of Cecropia sciadophylla in the Amazon suggest not only that a fast growing tropical pioneer tree species can emit volatile isoprenoids but also that leaf emission rates of highly reactive monoterpenes such as cis- and trans- $\beta$-ocimene were among the highest observed from trees globally (Jardine et al., 2015).

Although volatile isoprenoid emissions are highly species specific, methanol emissions appear to be a universal feature in plants attributed to the hydrolysis of cell wall methyl esters during changes in cell wall chemical and physical properties (Fall, 2003; Fall and Benson, 1996). Leaf methanol emissions have been shown to closely correlate with plant growth rates, especially at the early stages of leaf development with young leaves consistently observed to be higher emitters than mature leaves (Hüve et al., 2007; NemecekMarshall et al., 1995). In contrast, Is emission capacity has been reported to increase considerably throughout leaf development in close connection with photosynthetic capacity (Alves et al., 2014). However, phenological controls on both methanol and Is emissions have not been studied together in tropical plants.

As a part of Observations and Modeling of the Green Ocean Amazon (GoAmazon 2014/5) (Martin et al., 2016), we hypothesized that despite the high carbon and energy costs that could otherwise be used for growth and maintenance, the highly abundant pantropical pioneer tree species $V$. guianensis dedicates a significant fraction of recent photoassimilated carbon to volatile isoprenoid emissions due to their protective properties under abiotic stress. We further hypothesized that this fraction changes as a function of light intensity due to the well-documented light suppression of mitochondrial respiration at low light (e.g., the Kok effect) which results in a large increase in Pn but only a relatively small increase in gross photosynthesis (Sharp et al., 
1984). In addition, recent mechanistic Is emission models suggest that during high-light conditions where Pn is lightsaturated, emissions of Is (and other volatile isoprenoids) may continue to increase with increasing light due to increased excess available energy and reducing power for the methylerythritol 4-phosphate (MEP) pathway (Grote et al., 2014). Consistent with this model, a survey of tropical vegetation revealed strong light-dependent Is emission rates 23 times higher than those of temperate species (Lerdau and Keller, 1997). Moreover, tropical leaves did not demonstrate a light-saturation in Is emissions, which continued to increase with light up to $2500 \mathrm{~mol} \mathrm{~m}^{-2} \mathrm{~s}^{-1}$, the highest photosynthetically active radiation (PAR) fluxes studied (Lerdau and Keller, 1997). Thus, although biochemical and modeling studies have identified mechanisms expected to cause significant deviations between a constant linear ratio of volatile isoprenoid emissions and $\mathrm{Pn}$ as a function of light, experimental observations in the tropics are extremely limited to investigate these processes. Moreover, as laboratory studies have shown the classic uncoupling between net photosynthesis and Is emissions occurs in tropical plants at high leaf temperatures, little in situ information exists on this phenomenon in the tropics.

Here we first present new in situ observations during 2014 of leaf Is emissions and $\mathrm{Pn}$ as a function of light intensity from $V$. guianensis in the central Amazon together with a reanalysis of light-dependent monoterpene emissions from $C$. sciadophylla leaves in relation to Pn (Jardine et al., 2015). Second, we present the results leaf Is emissions and Pn responses in $V$. guianensis as a function of leaf temperature during 2015. Third, by taking advantage of the rapidly developing leaves of $V$. guianensis, we also test the hypothesis that leaf phenology differentially impacts methanol versus isoprenoid emissions. Finally, in order to further evaluate the potential for secondary tropical forests to be important atmospheric sources of isoprene, we present limited measurements of ambient daytime Is concentrations above a secondary rainforest ecosystem in the central Amazon. We end by discussing the potential physiological roles of volatile isoprenoids and methanol in secondary tropical rainforest ecosystems.

\section{Material and methods}

In this study, seven individuals of Vismia guianensis (Aubl.) Pers., a pioneer tree species from the Hypericaceae family, were studied in the Reserva Biológica do Cuieiras (ZF2), a primary rainforest biological reserve located approximately $60 \mathrm{~km}$ northwest of Manaus, in the central Amazon basin, Brazil. This reserve has an area of primary rainforest of roughly $230 \mathrm{~km}^{2}$ and is managed by the National Institute for Amazon Research (INPA). A nearby secondary rainforest ecosystem (ZF3 reserve), located approximately $105 \mathrm{~km}$ northwest of Manaus, was also studied for ambient concen- trations of Is at the top of the canopy $(\sim 25 \mathrm{~m})$ as a part of the biological dynamics of forest fragments project (Gascon and Bierregaard, 2001; see Fig. 1). Experimental data including GC-MS calibration slopes for Is, ambient Is concentrations, and leaf gas exchange response curves to light, temperature, and leaf age are available for download (see Data availability section; Jardine, 2016).

\subsection{Ambient concentrations of Is above the secondary forest canopy}

Six ambient air thermal desorption tube samples $\left(150 \mathrm{~mL} \mathrm{~min}^{-1}\right.$ for $\left.15 \mathrm{~min}\right)$ were sequentially collected at the canopy height of $25 \mathrm{~m}$ on a walk up tower at the ZF3 site (coordinates: $02^{\circ} 23^{\prime} 26.5^{\prime \prime} \mathrm{S}$ and $59^{\circ} 53^{\prime} 0.7^{\prime \prime} \mathrm{W}$ ) on 23 April 2015 between 11:38 and 13:18 LT. No samples were collected on two additional thermal desorption tubes for background analysis. The thermal desorption tubes were purchased commercially and filled with Quartz wool, Tenax TA, and Carbograph 5TD adsorbents (Markes International, UK) and analyzed for Is concentrations using a thermal desorption system interfaced with a gas chromatograph/mass spectrometer system (GC-MS) at INPA in Manaus, Brazil, as previously described (Jardine et al., 2014).

\subsection{Emission responses to light}

Emission responses to light for $V$. guianensis leaves under constant leaf temperature $\left(30^{\circ} \mathrm{C}\right)$ and reference $\left[\mathrm{CO}_{2}\right]$ $(400 \mathrm{ppm})$ were collected both in the field on intact branches and in the lab on detached branches during July 2014. Field observations of Is emissions and Pn for $V$. guianensis leaves as a function of PAR intensity $\left(0-2000 \mu \mathrm{mol} \mathrm{m}^{-2} \mathrm{~s}^{-1}\right)$ under constant leaf temperature $\left(30^{\circ} \mathrm{C}\right)$ were based on the coupling of the LI-6400XT with a portable thermal desorption tube sample collector as previously described (Jardine et al., 2015). Briefly, PAR values of $0,100,250,500,1000$, and $2000 \mu \mathrm{mol} \mathrm{m} \mathrm{m}^{-2} \mathrm{~s}^{-1}$ were established for $10 \mathrm{~min}$ each with a thermal desorption tube sample collected for each light level $\left(75 \mathrm{~mL} \mathrm{~min}^{-1} \times 10 \mathrm{~min}\right)$. Blank tubes were also collected without a leaf in the enclosure at the beginning of the experiment when the light level was $0 \mu \mathrm{mol} \mathrm{m}^{-2} \mathrm{~s}^{-1}$. Is emissions were quantified using a thermal desorption GCMS as previously described (Jardine et al., 2014). Emission responses to light were collected for two young and two young mature leaves from intact branches in the field (one individual). In addition, light-induced emission responses of detached branches (two individuals) were analyzed in the laboratory using proton transfer reaction/mass spectrometer (PTR-MS). For these laboratory experiments, an additional light level of $3000 \mu \mathrm{mol} \mathrm{m}^{-2} \mathrm{~s}^{-1}$ PAR was included to evaluate the saturation of Pn and Is emissions at high light intensities. Both the GC-MS and PTR-MS systems were calibrated to Is using dynamic dilution of a commercial compressed gas standard (2.0 ppm Is, Apel-Riemer Environmental). Monthly 

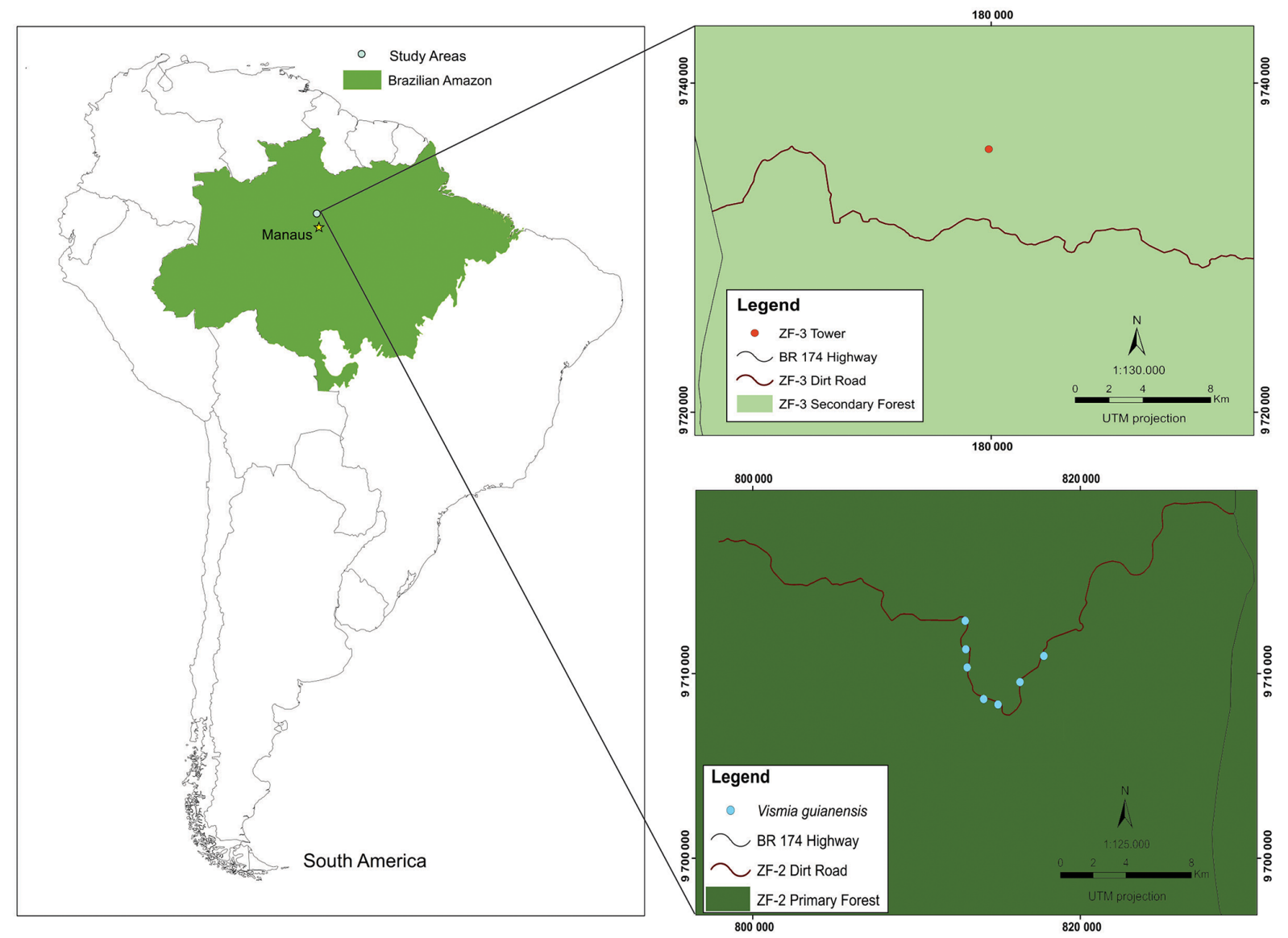

Figure 1. Location of the primary forest in the Reserva Biológica do Cuieiras (ZF2) and the secondary forest (ZF3) in the biological dynamics of forest fragments project near Manaus, Brazil.

GC-MS calibrations through a period that encompassed the July 2014 and 2015 field experiments (November 2013July 2015) demonstrated a high precision of Is quantitation by GC-MS; Is $m / z 67$ calibration slopes showed a relative standard deviation of $19.2 \%$.

\subsection{Emission responses to temperature}

Emission responses to temperature for $V$. guianensis leaves under constant PAR $\left(1000 \mu \mathrm{mol} \mathrm{m}^{-2} \mathrm{~s}^{-1}\right)$ and reference $\left[\mathrm{CO}_{2}\right](400 \mathrm{ppm})$ were collected on intact branches and in the field during July 2015. Field observations of Is emissions and Pn for $V$. guianensis leaves as a function of leaf temperature were conducted using the combined LI-6400XT/GC-MS system as described in Sect. 2.2. Leaf temperatures (25, 27.5, $30.0,32.5,35,37.5$, and $40^{\circ} \mathrm{C}$ ) were established for $10 \mathrm{~min}$ each with a thermal desorption tube sample collected for each temperature $\left(50-75 \mathrm{~mL} \mathrm{~min}^{-1} \times 10 \mathrm{~min}\right)$. Blank tubes were also collected without a leaf in the enclosure at the initial temperature of $25^{\circ} \mathrm{C}$ at the beginning of the experiment. Is emissions and $\mathrm{Pn}$ were quantified from five young mature leaves from intact branches in the field (one leaf per individual).

\subsection{Pn combined with Is and methanol emissions as a function of leaf age in $V$. guianensis}

In addition to being highly abundant in disturbed Amazon secondary forests (Mesquita, 2000), V. guianensis was selected because of its high leaf development rates, which produce two new apposing leaves roughly every month (G. Martins, personal communication, 2015). Leaves used were classified in three stages: young, young mature, and mature. For all plants, young leaves occurred at the top of the branch or the first leaf stage, young mature leaves occurring in the second leaf stage, and mature leaves occurring in the third leaf stage. For each leaf age experiment conducted during July 2014 in the field laboratory (six total individuals, one experiment per day), large branches roughly $1 \mathrm{~m}$ tall were detached from the tree around noon and immediately placed and recut in tap water before being transported to the field laboratory and analyzed for gas exchange within $15 \mathrm{~min}$ of being cut. Upon arriving in the laboratory, branches were 
placed under an LED plant growth light with between 300 and $600 \mu \mathrm{mol} \mathrm{m}{ }^{-2} \mathrm{~s}^{-1}$ PAR at branch height. As air temperature of the laboratory was roughly $25^{\circ} \mathrm{C}$, the PAR and air temperature environment in the laboratory was likely lower than the natural conditions under which the branch was removed. Leaf gas exchange measurements were initiated by placing a young leaf (first leaf stage) in the enclosure of a portable photosynthesis system (LI-6400XT, LI-COR Inc., USA) interfaced with a PTR-MS (Ionicon Analytik, Austria) as previously described (Jardine et al., 2014). Is and methanol emissions were quantified using the mass to charge ratios $m / z 69$ and 33, respectively, using PTR-MS, while Pn, stomatal conductance, and transpiration rates were quantified using the LI-6400XT. For each leaf age experiment, a single young leaf (first leaf stage), young mature leaf (second leaf stage), and mature leaf (third leaf stage) were sequentially placed inside the chamber for $15 \mathrm{~min}$ each. Before and after each leaf measurement, background measurements were collected for several minutes with an empty leaf chamber. Thus, the time required for each leaf age experiment was roughly $1 \mathrm{~h}$ beginning around noon, during July of 2014 . These leaf measurements were carried out under constant PAR flux $\left(1000 \mu \mathrm{mol} \mathrm{m}^{-2} \mathrm{~s}^{-1}\right)$, leaf temperature $\left(30^{\circ} \mathrm{C}\right)$, and reference $\left[\mathrm{CO}_{2}\right](400 \mathrm{ppm})$.

\section{Results and discussion}

\subsection{Ambient concentrations of Is above the secondary forest canopy}

To evaluate for the first time the potential role of secondary forests as source of Is to the lower tropical troposphere, we measured daytime ambient concentrations of Is at the top of a $\sim 25 \mathrm{~m}$ canopy in the ZF3 rainforest fragment site (Gascon and Bierregaard, 2001). Daytime ambient Is concentrations above secondary forest canopy at ZF3 where high (>10 ppb) and increased from 10.0 ppb at 11:38 LT to $10.9 \mathrm{ppb}$ by 12:30 LT. This was followed by a decrease to $10.5 \mathrm{ppb}$ by 13:03 LT, possibly due to the reduction of light and temperature from afternoon cloud formation. As Is concentrations from primary forests in the Amazon have been reported between 6 and $10 \mathrm{ppb}$ (Jardine et al., 2012b; Karl et al., 2009), these observations are consistent with the idea that tropical secondary forests represent an important source of Is in the lower troposphere.

\subsection{Emission responses to light}

In order to investigate the possibility that the highly abundant pantropical pioneer species $V$. guianensis dedicates a significant fraction of Pn to volatile isoprenoid emissions to the atmosphere, we first conducted controlled light experiments on intact branches in the field using a new portable photosynthesis and volatile organic compound emission system based on thermal desorption GC-MS (Jardine et al.,
2015). The results show that during the 2014 rainy season in the central Amazon (13 May 2014), light stimulation of Pn up to $15 \mu \mathrm{mol} \mathrm{m}{ }^{-2} \mathrm{~s}^{-1}$ in young mature leaves was associated with Is emissions, which continued to increase with light up to the maximum PAR intensity $\left(2000 \mu \mathrm{mol} \mathrm{m}^{-2} \mathrm{~s}^{-1}\right)$ where emission rates were $30 \mathrm{nmol} \mathrm{m}^{-2} \mathrm{~s}^{-1}$. These emission rates are higher than those reported by Harley et al. (2004) of roughly $11 \mathrm{nmol} \mathrm{m}^{-2} \mathrm{~s}^{-1}$ from a $V$. guianensis leaf in the National Forest Tapajós, near Santarém, Brazil (Harley et al., 2004). This emission rate is similar, however, to Is emissions observed by PTR-MS in this study during the 2014 dry season which ranged from 20 to $45 \mathrm{nmol} \mathrm{m}^{-2} \mathrm{~s}^{-1}$ under standard conditions of PAR and leaf temperature and up to $80 \mathrm{nmol} \mathrm{m}^{-2} \mathrm{~s}^{-1}$ at maximum PAR fluxes of $3000 \mu \mathrm{mol} \mathrm{m}^{-2} \mathrm{~s}^{-1}$ (see Fig. 2).

Although GC-MS results confirm that $V$. guianensis is a strong Is emitting species, Is collections on thermal desorption tubes at each environmental light level represent the average emission rate during each $10 \mathrm{~min}$ sample collection. Therefore, to analyze the relationship between Pn and Is emissions as a function of PAR in greater temporal detail, real-time PTR-MS measurements of Is emissions were collected simultaneously with real-time Pn measurements (Fig. 2a). The PTR-MS system was installed in the field laboratory and detached branches of $V$. guianensis growing just outside of the laboratory were utilized. Similar to the GC-MS measurements, $V$. guianensis showed negligible Is emissions in the dark where Pn was negative (likely due to mitochondrial respiration and the absence of photosynthesis). Moreover, upon first switching on the light, Pn sharply increased from slightly negative in the dark to around $5.0 \mu \mathrm{mol} \mathrm{m}^{-2} \mathrm{~s}^{-1}$ at a PAR flux of $100 \mu \mathrm{mol} \mathrm{m}^{-2} \mathrm{~s}^{-1}$. With every increase in PAR up to the maximum of $3000 \mu \mathrm{mol} \mathrm{m}^{-2} \mathrm{~s}^{-1}$, Is emissions continued to increase without any sign of saturation. In contrast, although Pn also increased with PAR, it essentially saturated at PAR fluxes above $2000 \mu \mathrm{mol} \mathrm{m}^{-2} \mathrm{~s}^{-1}$. Thus, when carbon flux emitted as Is was plotted against Pn, a strong nonlinear relationship was observed (Fig. 2b). As Pn increased with PAR, the fraction of Pn dedicated to Is emissions increased up to $1.9 \%$. This nonlinear effect could not be explained by an increase in leaf temperature as PAR increased; throughout the range of PAR values, leaf temperatures remained between $30 \pm 1^{\circ} \mathrm{C}$.

In light of the nonlinear relationship between the fraction of Pn dedicated to Is emissions and Pn for the pioneer species $V$. guianensis, we analyzed previously reported lightdependent monoterpene data from the abundant pantropical pioneer species $C$. sciadophylla for a similar nonlinear relationship (Jardine et al., 2015). The results of the C. sciadophylla reanalysis also revealed a strong nonlinear relationship between the fraction of Pn emitted as monoterpenes and Pn during controlled light experiments (graph not shown). The fraction of Pn dedicated to monoterpene emissions continued to increase with PAR up to $1.9 \%$ at maximum PAR. Thus, both $V$. guianensis and $C$. sciadophylla ded- 

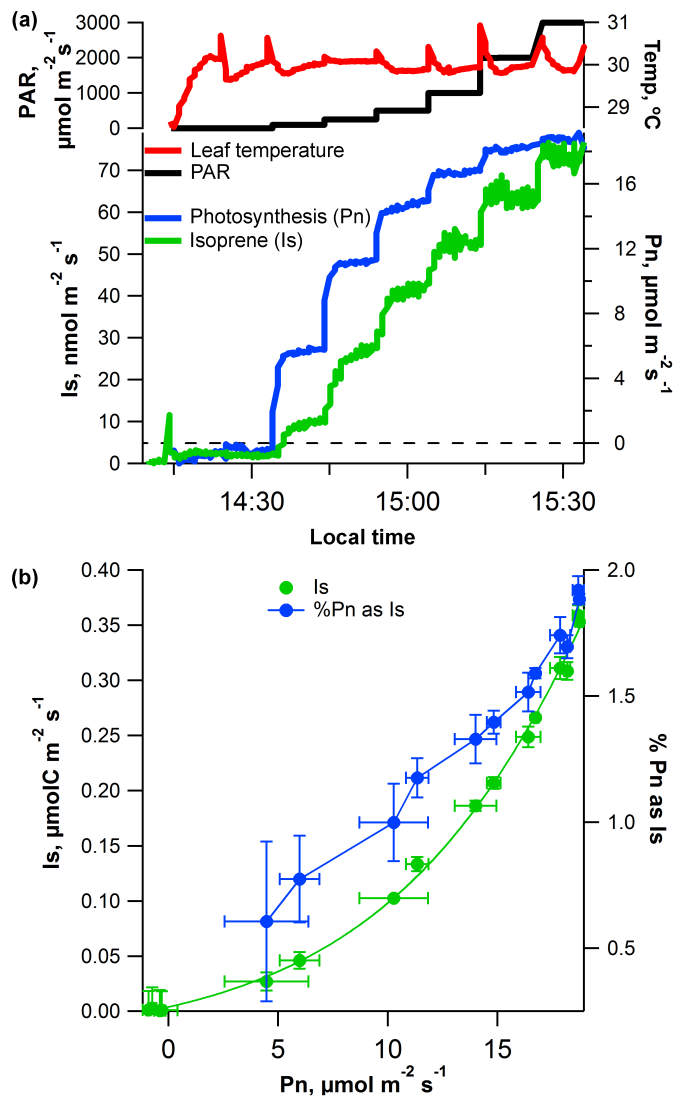

Figure 2. Real-time leaf net photosynthesis and isoprene emissions as a function of light intensity in the fast growing pantropical pioneer species V. guianensis. (a) Example time series plot of net photosynthesis (Pn) and isoprene emission (Is) together with leaf temperature (temp) and photosynthetically active radiation (PAR) during a controlled light experiment under constant leaf temperature $\left(30 \pm 1^{\circ} \mathrm{C}\right)$. (b) Is expressed in $\mu \mathrm{mol} \mathrm{C} \mathrm{m}^{-2} \mathrm{~s}^{-1}$ plotted against $\mathrm{Pn}$ $\left(\mu \mathrm{mol} \mathrm{m} \mathrm{m}^{-2} \mathrm{~s}^{-1}\right)$. Also shown is the increase in \% Pn dedicated to Is as a function of Pn. Pn was determined by a portable photosynthesis system (LI-6400XT, LI-COR Inc., USA) and Is by a proton transfer reaction/mass spectrometer (PTR-MS, Ionicon Analytik, Austria).

icate roughly $2 \%$ of Pn to volatile isoprenoid emissions at $30^{\circ} \mathrm{C}$ leaf temperature and show a strong increase in the fraction of Pn dedicated to volatile isoprenoid emissions as PAR increases. These observations are consistent with a growing body of evidence that the fraction of assimilated carbon transformed to volatile isoprenoids increases with leaf energetic status (including high light and low atmospheric $\mathrm{CO}_{2}$ concentrations) (Morfopoulos et al., 2014). While not captured by common Is emission algorithms, the increased allocation of Pn to volatile isoprenoid emissions is captured by energetic models of Is emissions (Morfopoulos et al., 2014). These observations imply that the functional roles of volatile isoprenoids are particularly important under high-light conditions and could potentially be explained by a competition between photosynthesis and the MEP pathway for adenosine triphosphate (ATP) and nicotinamide adenine dinucleotide phosphate (NADPH) generated by the light reactions of photosynthesis (Grote et al., 2014).

Under low light conditions, the Benson-Calvin cycle dominates the consumption of ATP and NADPH, resulting in relatively large increases in Pn with a correspondingly small increase in volatile isoprenoid production. In contrast, under light saturated conditions for Pn, excess ATP and NADPH are consumed by the MEP pathway, resulting in a relatively small increase in Pn with a correspondingly large increase in volatile isoprenoid production. Finally, the Kok effect may further contribute to this nonlinear relationship at low light levels (Sharp et al., 1984). Low PAR fluxes around the light compensation point for Pn have been shown to partially suppress mitochondrial respiration, which results in a relatively small increase in gross photosynthesis and a correspondingly large increase in Pn. Thus, at low light levels, this would further contribute to a relatively large increase in Pn with a correspondingly small increase in Is emissions.

\subsection{Emission responses to temperature}

A strong uncoupling of Is emissions and Pn was observed as a function of leaf temperature in each of the $V$. guianensis leaves studied from five individuals (Fig. 3). For three of the five leaves, $\mathrm{Pn}$ increased together with temperature and showed a clear optimum temperature of $30-32.5^{\circ} \mathrm{C}$ and decreased at higher temperatures. The other two leaves showed decreases in Pn as temperatures increased above $25^{\circ} \mathrm{C}$. Thus, a relatively high standard deviation occurred at the lowest leaf temperature $\left(25^{\circ} \mathrm{C}\right)$ and a clear optimum in Pn between 30 and $32.5^{\circ} \mathrm{C}$ was generally not observable from the average. Nonetheless, above $30-32.5^{\circ} \mathrm{C}$, all five leaves showed a strong decrease in Pn.

In contrast, Is emissions from all five leaves increased with leaf temperatures above $25^{\circ} \mathrm{C}$; Is emissions continued to increase even while Pn was strongly suppressed up to the highest leaf temperatures studied $\left(40^{\circ} \mathrm{C}\right)$. Therefore, distinct temperature optima for $\mathrm{Pn}\left(30.0-32.5^{\circ} \mathrm{C}\right)$ and $\mathrm{Is}\left(>40^{\circ} \mathrm{C}\right)$ exist for $V$. guianensis leaves. This classic uncoupling has been shown to be influenced by the use of "alternate" Is carbon sources, including potential extrachloroplastic substrates (Rosenstiel et al., 2004; Loreto et al., 2004; Karl et al., 2002), as well as the integration of photorespiratory substrates into the Calvin cycle and the re-assimilation of internally produced $\mathrm{CO}_{2}$ (e.g., respiration, photorespiration) (Jardine et al., $2014,2010)$. At the highest leaf temperature studied $\left(40^{\circ} \mathrm{C}\right)$, $7 \%$ of the Pn on average was emitted from V. guianensis leaves in the form of Is.

Interestingly, $V$. guianensis also produces large quantities of red latex as an herbivore deterrent (Almeida-Cortez and Melo-de-Pinna, 2006). Although latex, or cis-polyisoprene, is produced within the cytosol by the mevalonate pathway, whereas Is is produced within the chloroplasts by the MEP pathway, exchange of common intermediates such as isopen- 


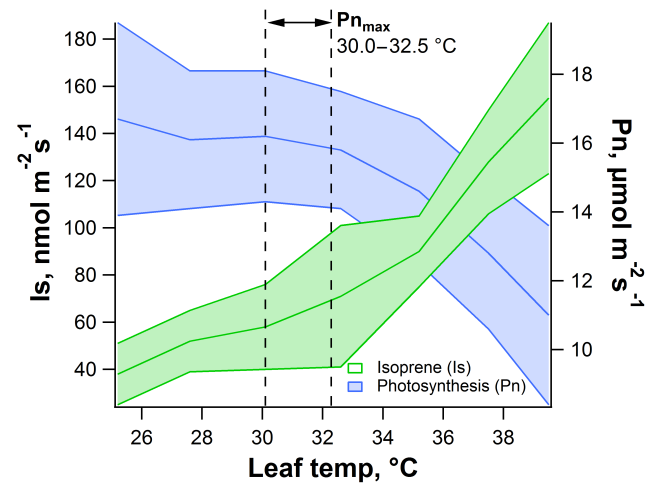

Figure 3. Average net photosynthesis (Pn) and isoprene emissions (Is) from $V$. guianensis leaves as a function of leaf temperature (average \pm 1 standard deviation, $n=5$ leaves) under constant PAR of $1000 \mu \mathrm{mol} \mathrm{m}^{-2} \mathrm{~s}^{-1}$ and $400 \mathrm{ppm}$ reference $\left[\mathrm{CO}_{2}\right]$. Note the decline in $\mathrm{Pn}$ and the increase in Is with leaf temperature above 30.0$32.5^{\circ} \mathrm{C}$, where the majority of leaves showed an optimum in Pn. Pn was determined with a portable photosynthesis system (LI-6400XT, LI-COR Inc., USA) and Is was determined using thermal desorption GC-MS.

tenyl diphosphate (IDP) may occur (Chow et al., 2007). These data build on previous studies in Asia, which demonstrated that latex producing trees can be strong emitters of volatile isoprenoids (Wang et al., 2007; Baker et al., 2005).

\subsection{Pn combined with Is and methanol emissions as a function of leaf age in $V$. guianensis}

A well-defined pattern of photosynthesis and Is/methanol emissions was observed according the leaf age of $V$. guianensis as shown in real-time during two example leaf age experiments (Fig. 4) and as an average of six leaf age experiments (Fig. 5). The results show that young leaves had low Pn rates $\left(2.7 \pm 2.2 \mu \mathrm{mol} \mathrm{m}^{-2} \mathrm{~s}^{-1}\right)$, high methanol emissions $\left(24 \pm 13 \mathrm{nmol} \mathrm{m}^{-2} \mathrm{~s}^{-1}\right)$, but low to undetectable Is emissions $\left(2.1 \pm 0.2 \mathrm{nmol} \mathrm{m}^{-2} \mathrm{~s}^{-1}\right)$. In contrast, young mature leaves had high Pn rates $\left(12.9 \pm 5.2 \mu \mathrm{mol} \mathrm{m}^{-2} \mathrm{~s}^{-1}\right)$, low methanol emissions $\left(3.3 \pm 1.5 \mathrm{nmol} \mathrm{m}^{-2} \mathrm{~s}^{-1}\right)$, but high Is emissions $\left(35.7 \pm 9.1 \mathrm{nmol} \mathrm{m}^{-2} \mathrm{~s}^{-1}\right)$. In addition, mature leaves also showed the same pattern as young mature leaves with high Pn rates $\left(10.6 \pm 5.2 \mu \mathrm{mol} \mathrm{m}^{-2} \mathrm{~s}^{-1}\right)$, low methanol emissions $\left(3.0 \pm 1.1 \mathrm{nmol} \mathrm{m}^{-2} \mathrm{~s}^{-1}\right)$, but high Is emissions $\left(39.8 \pm 6.0 \mathrm{nmol} \mathrm{m}^{-2} \mathrm{~s}^{-1}\right)$.

There is a wide range of morphological characteristics, chemical compositions, and physiological activities of leaves depending on the developmental stage of the plant or tissue (Forrest and Miller-Rushing, 2010; Richardson et al., 2013). In the case of photosynthesis, increased light harvesting components, electron transport rates, and carboxylation efficiency occur in parallel with the growth and development of leaves (Reich et al., 2009; Kikuzawa, 1995; Merilo et al., 2009). The lower Pn rates observed in young V. guianen- sis leaves compared to mature leaves (Fig. 5) is a pattern that is routinely observed in numerous studies (Alves et al., 2014; Reich et al., 1991). The relationship between photosynthetic activity and leaf development can be explained, in part, by the development of chloroplasts (Massad et al., 2012; Hikosaka, 2003). Previous studies have confirmed increased levels of amino acids, proteins, nucleic acids, and pigments during leaf development, together with greater rates of carboxylation (Lohman et al., 1994; Buchanan-Wollaston and Ainsworth, 1997; Egli and Schmid, 1999). Is from V. guianensis leaves observed in this study also followed a similar developmental pattern to that of Pn rates. This result is consistent with previous observations that in the early stages of leaf growth, photoassimilates tend to be partitioned towards growth compounds at the expense of defense compounds (Massad et al., 2012). This behavior can partially be explained by a limitation in substrate for Is in young leaves because photosynthesis is one of the main processes responsible for providing the required carbon intermediates, reducing equivalents, and ATP needed to produce dimethylallyl pyrophosphate (DMAPP) required for Is biosynthesis (Loivamaki et al., 2007; Sun et al., 2013). However, the demand for DMAPP is very high during leaf expansion because this compound is essential for the synthesis of all plant isoprenoids including photosynthetic pigments (Hannoufa and Hossain, 2012; Domonkos et al., 2013; Eisenreich et al., 2004; Opitz et al., 2014). Thus, due to the limited availability of DMAPP in young rapidly expanding leaves, a competition occurs for this substrate such that a larger fraction is allocated towards photosynthetic pigments (Rasulov et al., 2014). However, once the photosynthetic machinery is in place, a larger fraction of DMAPP may be dedicated to Is production and emissions (Rasulov et al., 2014). Once the photosynthetic machinery is established, high Is production rates may help protect against photoinhibition and photooxidation by consuming excess energy and reducing equivalents during conditions of light saturation for photosynthesis. Moreover, the antioxidant properties of Is have been well demonstrated (Jardine et al., 2012a; Vickers et al., 2009a; Loreto et al., 2001; Affek and Yakir, 2002). Is production lowers lipid peroxidation, quenches reactive oxygen species, and protects photosynthesis under oxidative stress (Loreto and Velikova, 2001). Previous studies have demonstrated the protective role of Is for photosynthesis during high leaf temperature stress (Sharkey et al., 2001) and a potential antioxidant mechanism was supported by the detection of Is oxidation products for high-temperature stress (Jardine et al., 2012a, 2013).

In contrast to Pn and Is, emissions of methanol from $V$. guianensis leaves were 8 times higher in young leaves than in mature leaves (Fig. 5), similar to patterns found in the literature from leaves of mid-latitude trees (Harley et al., 2007; Nemecek-Marshall et al., 1995; Hüve et al., 2007). Emissions of methanol have been closely associated with leaf growth rates (Hüve et al., 2007) caused primarily by the expansion of cell walls (Fall, 2003). As a consequence, young 

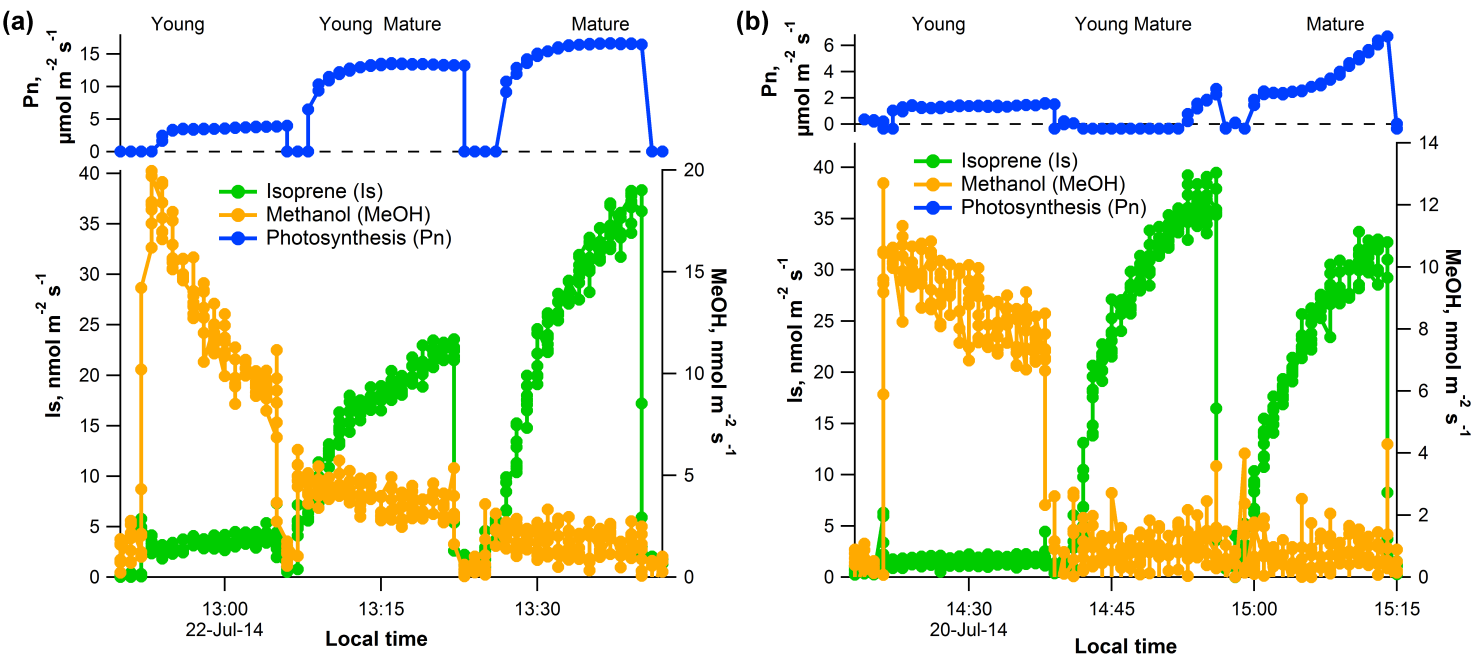

Figure 4. Example leaf age experiments of net photosynthesis (Pn, blue circles), methanol emissions (MeOH, orange circles) and isoprene emissions (Is, green circles) from two V. guianensis individuals. For each plant shown in panels (a) and (b) a young, young mature, and mature leaf were sequentially placed in the leaf enclosure for $15 \mathrm{~min}$ each after exposed to laboratory conditions following transport from the field. Throughout the leaf age experiments, PAR, leaf temperature, and reference $\left[\mathrm{CO}_{2}\right]$ were held constant at $1000 \mu \mathrm{mol} \mathrm{m}{ }^{-2} \mathrm{~s}^{-1}, 30^{\circ} \mathrm{C}$, and $400 \mathrm{ppm}$, respectively. Pn was determined by a portable photosynthesis system (LI-6400XT, LI-COR Inc., USA). Is and MeOH were determined by a proton transfer reaction/ mass spectrometer (PTR-MS, Ionicon Analytik, Austria).

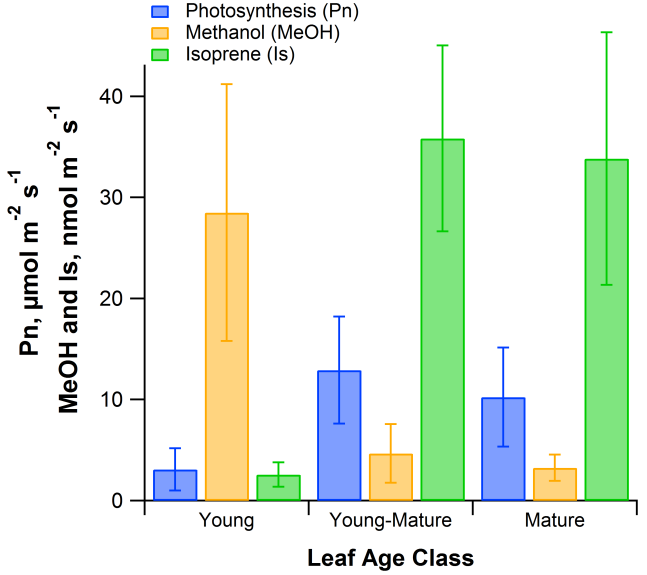

Figure 5. Average net photosynthesis rates (Pn, blue bars) together with leaf emissions of isoprene (Is, green bars) and methanol (MeOH, orange bars) for six V. guianensis individuals. For each individual, volatile emissions and net photosynthesis rates were determined from young, young mature, and mature leaves. Error bars represent \pm 1 standard deviation (six individuals, one branch per individual, one young, one young mature, and one mature leaf per branch). Pn was determined by a portable photosynthesis system (LI-6400XT, LI-COR Inc., USA), and Is and MeOH by a proton transfer reaction/mass spectrometer (PTR-MS, Ionicon Analytik, Austria).

rapidly expanding leaves have consistently been observed to have higher methanol emissions than mature leaves (Hüve et al., 2007; Nemecek-Marshall et al., 1995). Methanol production is thought to be initiated during pectin demethylation re- actions catalyzed by the enzyme pectin methylesterase (Bai et al., 2014). In this reaction, the hydrolysis of galacturonic acid methyl esters strengthens the cell wall while liberating methanol as a by-product (Hüve et al., 2007; Harley et al., 2007; Bai et al., 2014; Hanson and Roje, 2001). High rates of methanol emission may be associated with higher catalytic activity of this enzyme (Galbally and Kirstine, 2002; Hüve et al., 2007). In addition to growth processes, high methanol emissions have also been observed during stress and senescence processes (Cosgrove, 2005, 1999), possibly also mediated by pectin demethylation reactions during physicochemical changes to cell walls. Thus, the high methanol emissions from young leaves of $V$. guianensis may be due to both growth and stress processes.

\subsection{Potential roles of volatile isoprenoids and methanol in secondary tropical ecosystems}

High emission rates of volatile isoprenoids have been observed from dominant central Amazon pioneer species including $V$. guianensis (this study) and C. sciadophylla (Jardine et al., 2015) as well early successional species in central Africa (Klinger et al., 1998). Although a systematic survey of pioneer tree species in the tropics is needed, the potential for widespread occurrence of Is emissions from secondary forest tree species is supported by the single midday set of observations of high ambient Is concentrations (11.0 ppbv) above a diverse secondary rainforest canopy in the central Amazon. The observations of increased Pn allocation to volatile isoprenoid emissions as a function of light intensity provides additional support for a functional role of 
volatile isoprenoid biosynthesis in minimizing photoinhibition by consuming excess photosynthetic energy and reducing equivalents (Morfopoulos et al., 2014) as well as other potential direct and indirect antioxidant activities (Jardine et al., 2012a; Vickers et al., 2009a; Velikova and Loreto, 2005).

The nonlinear relationship between Is emissions and Pn in $V$. guianensis leaves is consistent with a suppression of mitochondrial respiration at low light (Sharp et al., 1984) and an increased dedication of photoassimilated carbon to Is biosynthesis via the MEP pathway under light saturating conditions of $\mathrm{Pn}$, possibly due to the utilization of excess available energy and reducing equivalents (Morfopoulos et al., 2014). These observations are consistent with volatile isoprenoids offering substantial protection to the photosynthetic machinery against photoinhibition and oxidative damage under stress conditions such as high-light and leaf temperature environments that are regularly experienced by secondary forests. In the case of $V$. guianensis, we observed that Is emissions and photosynthesis rates increase together throughout leaf development, while methanol emissions decreased. Although not easily distinguished in the present data set due to the low temporal resolution of leaf development observations (roughly monthly resolved ages categorized into young, young mature, and mature), Pn has been shown to proceed Is emissions in young developing leaves by several days to several weeks (Monson et al., 1994; Kuzma and Fall, 1993; Grinspoon et al., 1991). Methanol emission patterns are also consistent with previous observations which have shown strong positive relationships between leaf expansion rates and methanol emissions (Grinspoon et al., 1991). Similar observations have been made at the ecosystem scale in a mixed hardwood forest in northern Michigan, USA, during the spring growing season when a strong enhancement in ecosystem emissions of methanol were observed together with an increase in leaf area index (Karl et al., 2003).

\section{Conclusion}

The findings of this study show that abundant secondary rainforest tree species (e.g., V. guianensis and C. sciadophylla) contribute high emissions of volatile isoprenoids to the atmosphere that represent up to $2 \%$ of Pn under the standard leaf temperature of $30^{\circ} \mathrm{C}$ and up to $7 \%$ under $40^{\circ} \mathrm{C}$, the carbon and energy costs notwithstanding. Thus, the hypothesis that fast growing pioneer tree species in secondary tropical forests do not produce volatile isoprenoids, and instead dedicate these carbon and energy resources to enhanced growth and respiration demands, is not supported.

High emission rates of volatile isoprenoids have been observed from dominant central Amazon pioneer species including V. guianensis (this study) and C. sciadophylla (Jardine et al., 2015) as well early successional species in central Africa (Klinger et al., 1998). Although a systematic survey of pioneer tree species in the Amazon is needed, the po- tential for widespread occurrence of Is emissions from secondary forest tree species is supported by the single midday set of observations of high ambient Is concentrations (11.0 ppbv) above a diverse secondary rainforest canopy in the central Amazon. The observations of increased Pn allocation to volatile isoprenoid emissions as a function of light intensity provides additional support for a functional role of volatile isoprenoid biosynthesis in minimizing photoinhibition by consuming excess photosynthetic energy and reducing equivalents (Morfopoulos et al., 2014) as well as other potential direct and indirect antioxidant activities (Jardine et al., 2012a; Vickers et al., 2009a; Velikova and Loreto, 2005). Together with previous studies, our observations support a functional role for methanol production during cell wall expansion during growth (Fall, 2003) and the establishment of photosynthetic machinery and a defense role for volatile isoprenoid production to help protect this photosynthetic machinery against the abiotic stresses (Vickers et al., 2009a) that are commonly experienced in secondary rainforest ecosystems.

\section{Data availability}

The data used in this manuscript is available for download for research and educational purposes at the following web link maintained by Lawrence Berkeley National Laboratory: https://www.dropbox.com/sh/hr5ucem69m6dbhq/ AABIK5QrnfRMg4UhNLWnAJYya?dl=0.

Acknowledgements. We acknowledge the support from the Central Office of the Large Scale Biosphere Atmosphere Experiment in Amazonia (LBA), the Instituto Nacional de Pesquisas da Amazonia (INPA), and the Universidade do Estado do Amazonia (UEA). We would like to especially thank INPA researchers Giordane Martins and Ana Paula Florentino for introducing our team to the fascinating science involving the fast growing pioneer species Vismia guianensis. This material is based upon work supported as part of the GoAmazon 2014/5 and the Next Generation Ecosystem Experiments - Tropics (NGEE-Tropics) funded by the US Department of Energy, Office of Science, Office of Biological and Environmental Research, through contract no. DE-AC02-05CH11231 to LBNL, as part of DOE's Terrestrial Ecosystem Science Program.

Edited by: T. Petäjä

\section{References}

Affek, H. P. and Yakir, D.: Protection by isoprene against singlet oxygen in leaves, Plant Physiol., 129, 269-277, doi:10.1104/pp.010909, 2002.

Almeida-Cortez, J. and Melo-de-Pinna, G.: Morphology and anatomy of a leaf mine in Vismia guianensis (Aubl.) Choisy (Clusiaceae) in a fragment of Brazilian Atlantic forest, Braz. J. Biol., 66, 759-763, doi:10.1590/S1519-69842006000400021, 2006. 
Alves, E. G., Harley, P., Gonçalves, J. F. d. C., Moura, C. E. d. S., and Jardine, K.: Effects of light and temperature on isoprene emission at different leaf developmental stages of eschweilera coriacea in central Amazon, Acta Amazonica, 44, 918, doi:10.1590/S0044-59672014000100002, 2014.

Bai, Y.-R., Yang, P., Su, Y.-Y., He, Z.-L., and Ti, X.-N.: Effect of exogenous methanol on glycolate oxidase and photorespiratory intermediates in cotton, J. Exp. Bot., 65, 5331-5338, 2014.

Baker, B., Bai, J.-H., Johnson, C., Cai, Z.-T., Li, Q.-J., Wang, Y.-F., Guenther, A., Greenberg, J., Klinger, L., and Geron, C.: Wet and dry season ecosystem level fluxes of isoprene and monoterpenes from a southeast Asian secondary forest and rubber tree plantation, Atmos. Environ., 39, 381-390, doi:10.1016/j.atmosenv.2004.07.033, 2005.

Brienen, R. J., Phillips, O. L., Feldpausch, T. R., Gloor, E., Baker, T. R., Lloyd, J., Lopez-Gonzalez, G., Monteagudo-Mendoza, A., Malhi, Y., Lewis, S. L., Vasquez Martinez, R., Alexiades, M., Alvarez Davila, E., Alvarez-Loayza, P., Andrade, A., Aragao, L. E., Araujo-Murakami, A., Arets, E. J., Arroyo, L., Aymard, C. G., Banki, O. S., Baraloto, C., Barroso, J., Bonal, D., Boot, R. G., Camargo, J. L., Castilho, C. V., Chama, V., Chao, K. J., Chave, J., Comiskey, J. A., Cornejo Valverde, F., da Costa, L., de Oliveira, E. A., Di Fiore, A., Erwin, T. L., Fauset, S., Forsthofer, M., Galbraith, D. R., Grahame, E. S., Groot, N., Herault, B., Higuchi, N., Honorio Coronado, E. N., Keeling, H., Killeen, T. J., Laurance, W. F., Laurance, S., Licona, J., Magnussen, W. E., Marimon, B. S., Marimon-Junior, B. H., Mendoza, C., Neill, D. A., Nogueira, E. M., Nunez, P., Pallqui Camacho, N. C., Parada, A., PardoMolina, G., Peacock, J., Pena-Claros, M., Pickavance, G. C., Pitman, N. C., Poorter, L., Prieto, A., Quesada, C. A., Ramirez, F., Ramirez-Angulo, H., Restrepo, Z., Roopsind, A., Rudas, A., Salomao, R. P., Schwarz, M., Silva, N., Silva-Espejo, J. E., Silveira, M., Stropp, J., Talbot, J., ter Steege, H., Teran-Aguilar, J., Terborgh, J., Thomas-Caesar, R., Toledo, M., Torello-Raventos, M., Umetsu, R. K., van der Heijden, G. M., van der Hout, P., Guimaraes Vieira, I. C., Vieira, S. A., Vilanova, E., Vos, V. A., and Zagt, R. J.: Long-term decline of the Amazon carbon sink, Nature, 519, 344-348, doi:10.1038/nature14283, 2015.

Buchanan-Wollaston, V. and Ainsworth, C.: Leaf senescence in Brassica napus: cloning of senescence related genes by subtractive hybridisation, Plant Mol. Biol., 33, 821-834, doi:10.1023/A:1005774212410, 1997.

Bugmann, H.: A review of forest gap models, Climatic Change, 51, 259-305, 2001.

Chambers, J. Q., Robertson, A. L., Carneiro, V. M., Lima, A. J., Smith, M.-L., Plourde, L. C., and Higuchi, N.: Hyperspectral remote detection of niche partitioning among canopy trees driven by blowdown gap disturbances in the Central Amazon, Oecologia, 160, 107-117, doi:10.1007/s00442-008-1274-9, 2009.

Chow, K.-S., Wan, K.-L., Isa, M. N. M., Bahari, A., Tan, S.-H., Harikrishna, K., and Yeang, H.-Y.: Insights into rubber biosynthesis from transcriptome analysis of Hevea brasiliensis latex, $\mathrm{J}$. Exp. Bot., 58, 2429-2440, doi:10.1093/jxb/erm093, 2007.

Cosgrove, D. J.: Enzymes and other agents that enhance cell wall extensibility, Annu. Rev. Plant Biol., 50, 391-417, doi:10.1146/annurev.arplant.50.1.391, 1999.

Cosgrove, D. J.: Growth of the plant cell wall, Nat. Rev. Mol. Cell Biol., 6, 850-861, doi:10.1038/nrm1746, 2005.
Dani, K. G. S., Jamie, I. M., Prentice, I. C., and Atwell, B. J.: Increased ratio of electron transport to net assimilation rate supports elevated isoprenoid emission rate in eucalypts under drought, Plant Physiol., 166, 1059-1072, doi:10.1104/pp.114.246207, 2014.

Dias-Filho, M. B.: Physiological responses of Vismia guianensis to contrasting light environments, Revista Brasileira de Fisiologia Vegetal, 7, 35-40, 1995.

Domonkos, I., Kis, M., Gombos, Z., and Ughy, B.: Carotenoids, versatile components of oxygenic photosynthesis, Progress in lipid research, 52, 539-561, doi:10.1016/j.plipres.2013.07.001, 2013.

Egli, P. and Schmid, B.: Relationships between leaf nitrogen and limitations of photosynthesis in canopies of Solidago altissima, Acta Oecol., 20, 559-570, doi:10.1016/S1146-609X(00)86623$0,1999$.

Eisenreich, W., Bacher, A., Arigoni, D., and Rohdich, F.: Biosynthesis of isoprenoids via the non-mevalonate pathway, Cell. Mol. Life Sci., 61, 1401-1426, doi:10.1007/s00018-004-3381-z, 2004.

Fall, R.: Abundant oxygenates in the atmosphere: A biochemical perspective, Chem. Rev., 103, 4941-4951, doi:10.1021/cr0206521, 2003.

Fall, R. and Benson, A. A.: Leaf methanol - The simplest natural product from plants, Trends Plant Sci., 1, 296-301, doi:10.1016/S1360-1385(96)88175-0, 1996.

Forrest, J. and Miller-Rushing, A. J.: Toward a synthetic understanding of the role of phenology in ecology and evolution, Philos. T. R. Soc. B, 365, 3101-3112, doi:10.1098/rstb.2010.0145, 2010.

Friend, A. D., Lucht, W., Rademacher, T. T., Keribin, R., Betts, R., Cadule, P., Ciais, P., Clark, D. B., Dankers, R., and Falloon, P. D.: Carbon residence time dominates uncertainty in terrestrial vegetation responses to future climate and atmospheric $\mathrm{CO}_{2}, \mathrm{P}$. Natl. Acad. Sci., 111, 3280-3285, 2014.

Galbally, I. and Kirstine, W.: The production of methanol by flowering plants and the global cycle of methanol, J. Atmos. Chem., 43, 195-229, doi:10.1023/A:1020684815474, 2002.

Gascon, C. L. and Bierregaard Jr., R. O.: The biological dynamics of forest fragments project, in: Lessons from Amazonia, edited by: Bierregaard Jr., R. O., Gascon, C., Lovejoy, T. E., and Mesquita, R., CT: Yale, New Haven, USA, 31-42, 2001.

Glynn, C., Herms, D. A., Orians, C. M., Hansen, R. C., and Larsson, S.: Testing the growth-differentiation balance hypothesis: dynamic responses of willows to nutrient availability, New Phytol., 176, 623-634, 2007.

Grinspoon, J., Bowman, W. D., and Fall, R.: Delayed onset of isoprene emission in developing velvet bean (Mucuna sp.) leaves, Plant Physiol., 97, 170-174, 1991.

Grote, R., Morfopoulos, C., Niinemets, U., Sun, Z. H., Keenan, T. F., Pacifico, F., and Butler, T.: A fully integrated isoprenoid emissions model coupling emissions to photosynthetic characteristics, Plant Cell Environ., 37, 1965-1980, doi:10.1111/Pce.12326, 2014.

Hannoufa, A. and Hossain, Z.: Regulation of carotenoid accumulation in plants, Biocatalysis and Agricultural Biotechnology, 1, 198-202, doi:10.1016/j.bcab.2012.03.004, 2012.

Hanson, A. D. and Roje, S.: One-carbon metabolism in higher plants, Annu. Rev. Plant Biol., 52, 119-137, 2001. 
Harley, P., Vasconcellos, P., Vierling, L., Pinheiro, C. C. D., Greenberg, J., Guenther, A., Klinger, L., De Almeida, S. S., Neill, D., Baker, T., Phillips, O., and Malhi, Y.: Variation in potential for isoprene emissions among Neotropical forest sites, Glob. Change Biol., 10, 630-650, doi:10.1111/j.15298817.2003.00760.x, 2004.

Harley, P., Greenberg, J., Niinemets, Ü., and Guenther, A.: Environmental controls over methanol emission from leaves, Biogeosciences, 4, 1083-1099, doi:10.5194/bg-4-1083-2007, 2007.

Hikosaka, K.: A model of dynamics of leaves and nitrogen in a plant canopy: an integration of canopy photosynthesis, leaf life span, and nitrogen use efficiency, Am. Nat., 162, 149-164, doi:10.1086/376576, 2003.

Hüve, K., Christ, M., Kleist, E., Uerlings, R., Niinemets, Ü., Walter, A., and Wildt, J.: Simultaneous growth and emission measurements demonstrate an interactive control of methanol release by leaf expansion and stomata, J. Exp. Bot., 58, 1783-1793, 2007.

Jardine, A., Jardine, K., Fuentes, J., Martin, S., Martins, G., Durgante, F., Carneiro, V., Higuchi, N., Manzi, A., and Chambers, J.: Highly reactive light-dependent monoterpenes in the Amazon, Geophys. Res. Lett., 42, 1576-1583, 2015.

Jardine, K. J.: Light, temperature, and leaf age response curves in Vismia guianensis, available at: https://www.dropbox.com/sh/ hr5ucem69m6dbhq/AABIK5QrnfRMg4UhNLWnAJYya?dl=0, last access: April 2016.

Jardine, K. J., Sommer, E., Saleska, S., Huxman, T., Harley, P., and Abrell, L.: Gas Phase Measurements of Pyruvic Acid and Its Volatile Metabolites, Environ. Sci. Technol., 44, 2454-2460, doi:10.1021/es903544p, 2010.

Jardine, K. J., Abrell, L., Jardine, A., Huxman, T., Saleska, S., Arneth, A., Monson, R., Karl, T., Fares, S., Loreto, F., and Goldstein, A.: Within-plant isoprene oxidation confirmed by direct emissions of oxidation products methyl vinyl ketone and methacrolein, Glob. Change Biol., 18, 973-984, doi:10.1111/j.1365-2486.2011.02610.x, 2012a.

Jardine, K. J., Monson, R. K., Abrell, L., Saleska, S. R., Arneth, A., Jardine, A., Ishida, F. Y., Serrano, A. M. Y., Artaxo, P., Karl, T., Fares, S., Goldstein, A., Loreto, F., and Huxman, T.: Within-plant isoprene oxidation confirmed by direct emissions of oxidation products methyl vinyl ketone and methacrolein, Glob. Change Biol., 18, 973-984, 10.1111/j.1365-2486.2011.02610.x, 2012b.

Jardine, K. J., Meyers, K., Abrell, L., Alves, E. G., Serrano, A. M., Kesselmeier, J., Karl, T., Guenther, A., Chambers, J. Q., and Vickers, C.: Emissions of putative isoprene oxidation products from mango branches under abiotic stress, J. Exp. Bot., 64, 3697-3709, doi:10.1093/Jxb/Ert202, 2013.

Jardine, K. J., Chambers, J., Alves, E. G., Teixeira, A., Garcia, S., Holm, J., Higuchi, N., Manzi, A., Abrell, L., Fuentes, J. D., Nielsen, L. K., Torn, M. S., and Vickers, C. E.: Dynamic balancing of isoprene carbon sources reflects photosynthetic and photorespiratory responses to temperature stress, Plant Physiol., 166, 2051-2064, doi:10.1104/pp.114.247494, 2014.

Karl, T., Fall, R., Rosenstiel, T. N., Prazeller, P., Larsen, B., Seufert, G., and Lindinger, W.: On-line analysis of the ${ }^{13} \mathrm{CO}_{2}$ labeling of leaf isoprene suggests multiple subcellular origins of isoprene precursors, Planta, 215, 894-905, 2002.

Karl, T., Guenther, A., Spirig, C., Hansel, A., and Fall, R.: Seasonal variation of biogenic VOC emissions above a mixed hard- wood forest in northern Michigan, Geophys. Res. Lett., 30, 2186, doi:10.1029/2003g1018432, 2003.

Karl, T., Guenther, A., Turnipseed, A., Tyndall, G., Artaxo, P., and Martin, S.: Rapid formation of isoprene photo-oxidation products observed in Amazonia, Atmos. Chem. Phys., 9, 7753-7767, doi:10.5194/acp-9-7753-2009, 2009.

Kesselmeier, J., Ciccioli, P., Kuhn, U., Stefani, P., Biesenthal, T., Rottenberger, S., Wolf, A., Vitullo, M., Valentini, R., Nobre, A., Kabat, P., and Andreae, M. O.: Volatile organic compound emissions in relation to plant carbon fixation and the terrestrial carbon budget, Global Biogeochem. Cy., 16, 1126-1135, doi:10.1029/2001gb001813, 2002.

Kikuzawa, K.: Leaf phenology as an optimal strategy for carbon gain in plants, Can. J. Botany, 73, 158-163, doi:10.1139/b95019, 1995.

Klinger, L., Greenburg, J., Guenther, A., Tyndall, G., Zimmerman, P., M'bangui, M., Moutsamboté, J. M., and Kenfack, D.: Patterns in volatile organic compound emissions along a savannarainforest gradient in central Africa, J. Geophys. Res.-Atmos. (1984-2012), 103, 1443-1454, 1998.

Kuzma, J. and Fall, R.: Leaf isoprene emission rate is dependent on leaf development and the level of isoprene synthase, Plant Physiol., 101, 435-440, 1993.

Lerdau, M. and Keller, M.: Controls on isoprene emission from trees in a subtropical dry forest, Plant Cell Environ., 20, 569578, 1997.

Lewis, S. L., Brando, P. M., Phillips, O. L., van der Heijden, G. M., and Nepstad, D.: The 2010 amazon drought, Science, 331, 554-554, 2011.

Lohman, K. N., Gan, S., John, M. C., and Amasino, R. M.: Molecular analysis of natural leaf senescence in Arabidopsis thaliana, Physiol. Plantarum, 92, 322-328, doi:10.1111/j.13993054.1994.tb05343.x, 1994.

Loivamaki, M., Louis, S., Cinege, G., Zimmer, I., Fischbach, R. J., and Schnitzler, J. P.: Circadian rhythms of isoprene biosynthesis in grey poplar leaves, Plant Physiol., 143, 540-551, doi:10.1104/pp.106.092759, 2007.

Loreto, F. and Velikova, V.: Isoprene produced by leaves protects the photosynthetic apparatus against ozone damage, quenches ozone products, and reduces lipid peroxidation of cellular membranes, Plant Physiol., 127, 1781-1787, doi:10.1104/pp.010497, 2001.

Loreto, F., Mannozzi, M., Maris, C., Nascetti, P., Ferranti, F., and Pasqualini, S.: Ozone quenching properties of isoprene and its antioxidant role in leaves, Plant Physiol., 126, 993-1000, doi:10.1104/pp.126.3.993, 2001.

Loreto, F., Pinelli, P., Brancaleoni, E., and Ciccioli, P.: ${ }^{13} \mathrm{C}$ labeling reveals chloroplastic and extrachloroplastic pools of dimethylallyl pyrophosphate and their contribution to isoprene formation, Plant Physiol., 135, 1903-1907, 2004.

Malhi, Y., Roberts, J. T., Betts, R. A., Killeen, T. J., Li, W., and Nobre, C. A.: Climate change, deforestation, and the fate of the Amazon, Science, 319, 169-172, 2008.

Martin, S. T., Artaxo, P., Machado, L. A. T., Manzi, A. O., Souza, R. A. F., Schumacher, C., Wang, J., Andreae, M. O., Barbosa, H. M. J., Fan, J., Fisch, G., Goldstein, A. H., Guenther, A., Jimenez, J. L., Pöschl, U., Silva Dias, M. A., Smith, J. N., and Wendisch, M.: Introduction: Observations and Modeling of the Green Ocean 
Amazon (GoAmazon2014/5), Atmos. Chem. Phys., 16, 47854797, doi:10.5194/acp-16-4785-2016, 2016.

Massad, T. J., Dyer, L. A., and Vega, G.: Costs of defense and a test of the carbon-nutrient balance and growth-differentiation balance hypotheses for two co-occurring classes of plant defense, PLoS ONE, 7, e47554, doi:10.1371/journal.pone.0047554, 2012.

Merilo, E., Tulva, I., Räim, O., Kükit, A., Sellin, A., and Kull, O.: Changes in needle nitrogen partitioning and photosynthesis during 80 years of tree ontogeny in Picea abies, Trees, 23, 951-958, doi:10.1007/s00468-009-0337-9, 2009.

Mesquita, R. C., Ickes, K., Ganade, G., and Williamson, G. B.: Alternative successional pathways in the Amazon Basin, J. Ecol., 89, 528-537, doi:10.1046/j.1365-2745.2001.00583.x, 2001.

Mesquita, R. d. C. G.: Management of advanced regeneration in secondary forests of the Brazilian Amazon, Forest Ecol. Manag., 130, 131-140, doi:10.1016/S0378-1127(99)00174-7, 2000.

Monson, R., Harley, P., Litvak, M., Wildermuth, M., Guenther, A., Zimmerman, P., and Fall, R.: Environmental and developmental controls over the seasonal pattern of isoprene emission from aspen leaves, Oecologia, 99, 260-270, 1994.

Morfopoulos, C., Sperlich, D., Peñuelas, J., Filella, I., Llusià, J., Medlyn, B. E., Niinemets, Ü., Possell, M., Sun, Z., and Prentice, I. C.: A model of plant isoprene emission based on available reducing power captures responses to atmospheric $\mathrm{CO}_{2}$, New Phytol., 203, 125-139, 2014.

Nemecek-Marshall, M., MacDonald, R. C., Franzen, J. J., Wojciechowski, C. L., and Fall, R.: Methanol emission from leaves (enzymatic detection of gas-phase methanol and relation of methanol fluxes to stomatal conductance and leaf development), Plant Physiol., 108, 1359-1368, 1995.

Opitz, S., Nes, W. D., and Gershenzon, J.: Both methylerythritol phosphate and mevalonate pathways contribute to biosynthesis of each of the major isoprenoid classes in young cotton seedlings, Phytochemistry, 98, 110-119, doi:10.1016/j.phytochem.2013.11.010, 2014.

Pan, Y., Birdsey, R. A., Fang, J., Houghton, R., Kauppi, P. E., Kurz, W. A., Phillips, O. L., Shvidenko, A., Lewis, S. L., and Canadell, J. G.: A large and persistent carbon sink in the world's forests, Science, 333, 988-993, 2011.

Penuelas, J. and Llusia, J.: Linking photorespiration, monoterpenes and thermotolerance in Quercus, New Phytol., 155, 227-237, doi:10.1046/j.1469-8137.2002.00457.x, 2002.

Phillips, O. L., Aragão, L. E., Lewis, S. L., Fisher, J. B., Lloyd, J., López-González, G., Malhi, Y., Monteagudo, A., Peacock, J., and Quesada, C. A.: Drought sensitivity of the Amazon rainforest, Science, 323, 1344-1347, 2009.

Rasulov, B., Bichele, I., Laisk, A., and Niinemets, U.: Competition between isoprene emission and pigment synthesis during leaf development in aspen, Plant Cell Environ., 37, 724-741, doi:10.1111/pce.12190, 2014.

Reich, P., Uhl, C., Walters, M., and Ellsworth, D.: Leaf lifespan as a determinant of leaf structure and function among 23 Amazonian tree species, Oecologia, 86, 16-24, doi:10.1007/BF00317383, 1991.

Reich, P. B., Falster, D. S., Ellsworth, D. S., Wright, I. J., Westoby, M., Oleksyn, J., and Lee, T. D.: Controls on declining carbon balance with leaf age among 10 woody species in Australian woodland: do leaves have zero daily net carbon balances when they die?, New Phytol., 183, 153-166, doi:10.1111/j.14698137.2009.02824.x, 2009.

Richardson, A. D., Keenan, T. F., Migliavacca, M., Ryu, Y., Sonnentag, O., and Toomey, M.: Climate change, phenology, and phenological control of vegetation feedbacks to the climate system, Agr. Forest Meteorol., 169, 156-173, doi:10.1016/j.agrformet.2012.09.012, 2013.

Rosenstiel, T., Ebbets, A., Khatri, W., Fall, R., and Monson, R.: Induction of poplar leaf nitrate reductase: a test of extrachloroplastic control of isoprene emission rate, Plant Biol., 6, 12-21, 2004.

Sharkey, T. D., Chen, X. Y., and Yeh, S.: Isoprene increases thermotolerance of fosmidomycin-fed leaves, Plant Physiol., 125, 20012006, doi:10.1104/pp.125.4.2001, 2001.

Sharp, R. E., Matthews, M. A., and Boyer, J. S.: Kok Effect and the Quantum Yield of Photosynthesis Light Partially Inhibits Dark Respiration, Plant Physiol., 75, 95-101, doi:10.1104/pp.75.1.95, 1984.

Stamp, N.: Can the growth-differentiation balance hypothesis be tested rigorously?, Oikos, 107, 439-448, 2004.

Sun, Z., Hüve, K., Vislap, V., and Niinemets, Ü.: Elevated $\left[\mathrm{CO}_{2}\right]$ magnifies isoprene emissions under heat and improves thermal resistance in hybrid aspen, J. Exp. Bot., 64, 5509-5523, doi:10.1093/jxb/ert318, 2013.

Uhl, C., Buschbacher, R., and Serrao, E.: Abandoned pastures in eastern Amazonia. I. Patterns of plant succession, J. Ecol., 663681, doi:10.2307/2260566, 1988.

Velikova, V. and Loreto, F.: On the relationship between isoprene emission and thermotolerance in Phragmites australis leaves exposed to high temperatures and during the recovery from a heat stress, Plant Cell Environ., 28, 318-327, 2005.

Vickers, C. E., Gershenzon, J., Lerdau, M. T., and Loreto, F.: A unified mechanism of action for volatile isoprenoids in plant abiotic stress, Nat. Chem. Biol., 5, 283-291, doi:10.1038/nchembio.158, 2009a.

Vickers, C. E., Possell, M., Cojocariu, C. I., Velikova, V. B., Laothawornkitkul, J., Ryan, A., Mullineaux, P. M., and Hewitt, C. N.: Isoprene synthesis protects transgenic tobacco plants from oxidative stress, Plant Cell Environ., 32, 520-531, doi:10.1111/j.13653040.2009.01946.x, 2009b.

Vieira, I. C. G., de Almeida, A. S., Davidson, E. A., Stone, T. A., de Carvalho, C. J. R., and Guerrero, J. B.: Classifying successional forests using Landsat spectral properties and ecological characteristics in eastern Amazonia, Remote Sens. Environ., 87, 470-481, doi:10.1016/j.rse.2002.09.002, 2003.

Wang, Y. F., Owen, S. M., Li, Q.-J., and Penuelas, J.: Monoterpene emissions from rubber trees (Hevea brasiliensis) in a changing landscape and climate: chemical speciation and environmental control, Glob. Change Biol., 13, 2270-2282, doi:10.1111/j.13652486.2007.01441.x, 2007.

Zalamea, P.-C., Stevenson, P. R., Madriñán, S., Aubert, P.-M., and Heuret, P.: Growth pattern and age determination for Cecropia sciadophylla (Urticaceae), Am. J. Bot., 95, 263-271, doi:10.3732/ajb.95.3.263, 2008. 